\title{
In vivo response of heme-oxygenase-1 to metal ions released from metal-on-metal hip prostheses
}

\author{
ALINA BERAUDI $^{1,2}$, EVA BIANCONI ${ }^{3,4}$, SIMONA CATALANI $^{5}$, SILVIA CANAIDER $^{3,4}$, DALILA DE PASQUALE ${ }^{1}$, \\ PIETRO APOSTOLI ${ }^{5}$, BARBARA BORDINI $^{1}$, SUSANNA STEA $^{1}$, ALDO TONI ${ }^{1,6}$ and FEDERICA FACCHIN ${ }^{3,4}$ \\ ${ }^{1}$ Medical Technology Laboratory; ${ }^{2}$ PROMETEO Laboratory, Rizzoli RIT Department - Research, Innovation and Technology, \\ Rizzoli Orthopaedic Institute, I-40136 Bologna; ${ }^{3}$ Department of Experimental, Diagnostic and Specialty Medicine, (DIMES), \\ Unit of Histology, Embryology and Applied Biology, University of Bologna, I-40136 Bologna; \\ ${ }^{4}$ National Institute of Biostructures and Biosystems, I-00136 Roma; ${ }^{5}$ Unit of Occupational Health and Industrial Hygiene, \\ Department of Medical and Surgical Specialties, Radiological Sciences and Public Health, University of Brescia, \\ I-25100 Brescia; ${ }^{6}$ Orthopaedic Traumatology and Prosthetic Surgery and Revisions of Hip and Knee Implants,
} Rizzoli Orthopedic Institute, I-40136 Bologna, Italy

Received June 22, 2015; Accepted January 20, 2016

DOI: $10.3892 / \mathrm{mmr} .2016 .5245$

\begin{abstract}
Metal ion release and accumulation is considered to be a factor responsible for the high failure rates of metal-on-metal (MoM) hip implants. Numerous studies have associated the presence of these ions, besides other factors, including a hypoxia-like response and changes in $\mathrm{pH}$ due to metal corrosion leading to the induction of the oxidative stress response. The aim of the present study was to verify whether, in patients with a MoM hip prosthesis, mRNA and protein expression of HMOX-1 was modulated by the presence of metal ions and whether patients without prostheses exhibit a different expression pattern of this enzyme. The study was conducted on 22 matched pairs of patients with and without prostheses, for a total of 44 samples. Ion dosage was determined using inductively coupled plasma mass spectrometry equipped with dynamic cell reaction. $H M O X-1$ gene expression was quantified by reverse transcription-quantitative polymerase chain reaction and HMOX-1 protein expression was analyzed using an enzyme-linked immunosorbent assay. The results demonstrated that although there were significant differences in the metallic ion concentrations amongst the two groups of patients, there was no correlation between circulating levels of cobalt $(\mathrm{Co})$ and chromium $(\mathrm{Cr})$, and HMOX-1 gene and protein expression. Additionally, there was no significant difference in the protein expression levels of HMOX-1 between the two
\end{abstract}

Correspondence to: Dr Alina Beraudi, Medical Technology Laboratory, Rizzoli RIT Department - Research, Innovation and Technology, Rizzoli Orthopaedic Institute, 1/10 Via di Barbiano, I-40136 Bologna, Italy

E-mail: beraudi@tecno.ior.it

Key words: heme-oxygenase-1, cobalt, chromium, metal-on-metal hip prosthesis, oxidative stress groups. In conclusion, it was demonstrated that circulating Co and $\mathrm{Cr}$ ions released by articular prosthetics do not induce an increase in HMOX-1 mRNA and protein expression at least 3.5 years after the implant insertion. The present study suggests that involvement of HMOX-1 may be excluded from future studies and suggests that other antioxidant enzymes, including superoxide dismutase, glutathione peroxidase and reductase should be investigated.

\section{Introduction}

Since the 2010 voluntary withdrawal of DePuy ASR Hip Resurfacing System and ASR XL Acetabular System prompted by several studies showing high failure rates of these hip implants (1-3), careful attention has been given to metal-on-metal (MoM) hip prostheses. The European community (4), in line with the international scientific community (5) and the Consensus Statement (6), has decided to stop the use of MoM big head stemmed implants (diameter $\geq 36 \mathrm{~mm}$ ).

The high failure rate of these devices is well asserted by all national registers (7-10). One of the factors considered to be responsible for this, was the release and the systemic accumulation of surface released microparticles, nanoparticles and ions (articular and trunnion) (11). These prostheses were also associated with local aseptic lymphocytic vasculitis, pseudotumours and necrosis of surrounding tissues with consequent prosthetic failure (12-14).

The MoM alloys are usually composed of chromium (Cr, 26-30\%), molybdenum (Mo, 5-7\%) and cobalt (Co) (for balancing ISO 5832-12:2007 High-Carbon-Alloy).

The accumulation of Co leads to a pathological condition, defined as cobaltism, predominantly affecting the nervous, cardiac and thyroid systems (15). The biological activity of $\mathrm{Co}$ is dictated by the concentration of unbound ionic Co (II) (16-18). Amongst the categories at risk of cobaltism are patients with big head MoM prostheses, in addition to reported 
cases of occupational or iatrogenic exposure investigated by toxicology experts (19).

While risk levels have already been established for cases of occupational exposure (20), those for patients with prosthetics have only been suggested by The Medicine and Healthcare products Regulatory Agency (MHRA) (21) and by the Consensus Statement (6). They have been suggested to be $7 \mu \mathrm{g} / \mathrm{l}$ for $\mathrm{Cr}$ and $\mathrm{Co}$ circulating ions, although certain authors have proposed $4 \mu \mathrm{g} / \mathrm{l}$ as a precaution (22). In addition, the risk levels for urinary ions have not been established yet.

Numerous studies have correlated the presence of metal ions with the formation of reactive oxygen species (ROS) (23), whose systemic and local effects are well known in different tested models (24). The metal ions $\mathrm{Cr}$ (III) and Co (II) catalyze the conversion of hydrogen peroxide into reactive hydroxyl radicals by the Fenton reaction (25). In response to oxidative stress, the organism protects itself by upregulating several enzymes, including heme-oxygenase-1 (HMOX-1) (26).

HMOX-1 is a member of the oxidoreductase family and catalyses the degradation of heme in carbon monoxide, divalent iron and biliverdin. It is then converted in bilirubin, the most abundant endogenous antioxidant in mammalian tissues, responsible for a number of antioxidant activities (26).

HMOX-1 represents the inducible isoform of the antioxidant system of heme-oxygenase and its induction is due to the action of multiple oxidation factors, including certain heavy metals (27), such as Co and Cr.

As it is known that Co (II) can induce the expression of HMOX-1 to counteract oxidative stress, the aim of the present study was to verify whether mRNA and protein expression of HMOX-1 was modulated by the presence of metal ions in patients with a MoM prosthesis and whether patients without a prosthesis exhibited a different expression pattern.

\section{Materials and methods}

Patient enrolment. This study was approved by the Institutional Review Board of the Rizzoli Orthopaedic Institute (Bologna, Italy). All investigations were conducted in conformity with ethical principles of research, and informed consent for participation in the study was obtained from all enrolled patients. This parallel cohort study was designed in order to evaluate $H M O X-1$ expression in patients with/without MoM prosthetics, in correlation with Co and Cr levels in the blood and urine. It has been registered at clinicaltrials.gov with the identification number: NCT02427984.

Patients with primary coxarthrosis, on a waiting list for primary hip prosthesis intervention, were enrolled in the study as a control group (non-prosthetic group; $n=22$ ). These 22 patients were coupled with patients with aseptic loosening MoM hip prostheses (prosthetic group; $n=22$ ), matched for gender, age and smoking habits. The recruitment period was from March 2014 to October 2014. The exclusion criteria were the presence of other articular prostheses, sepsis or suspected sepsis, hematologic pathologies and rheumatoid arthritis. Each group (prosthetic and non-prosthetic) contained 17 women and 5 men, of which 4 were smokers and 18 were non-smokers or ex-smokers (who had not smoked for $>10$ years). The mean age \pm standard error of the mean of the patients in the prosthetic group was $64.9 \pm 1.9$ years and of the patients in the non-prosthetic group was 64.2 \pm 2.1 (Table I).

Sample collection. Peripheral blood samples (total, $18 \mathrm{ml}$ ) were obtained using a disposable intravenous cannula, the first $3 \mathrm{ml}$ were discarded to eliminate possible contamination by metals caused by the sampling system, then $10 \mathrm{ml}$ of blood were withdrawn and transferred into two separate trace element vacutainer tubes $(5 \mathrm{ml} / \mathrm{tube})$ containing ethylenediaminetetraacetic acid (BD Biosciences, Franklin Lakes, NJ, USA) for whole blood. An additional $5 \mathrm{ml}$ of blood aliquot was transferred into a trace element serum vacutainer tube and centrifuged at $800 \mathrm{x}$ g for $7 \mathrm{~min}$ at $4^{\circ} \mathrm{C}$ to obtain blood serum. Next, $1 \mathrm{ml}$ samples of whole blood and serum were immediately frozen and stored at $-80^{\circ} \mathrm{C}$ for the ion analysis. The remaining $4 \mathrm{ml}$ aliquot of blood was collected to isolate white cells using a density gradient separation medium Histopaque-1077 (Sigma-Aldrich, St. Louis, MO, USA), following the manufacturer's protocol. The blood sample was diluted 1:1 in PBS and was layered on $4 \mathrm{ml}$ of the Histopaque-1077 medium and centrifuged at $400 \times \mathrm{g}$ for $30 \mathrm{~min}$ at room temperature. The ring of white cells was collected and washed with $10 \mathrm{ml}$ of PBS centrifuging at $250 \mathrm{x}$ g for $10 \mathrm{~min}$ at room temperature. The cell pellet was resuspended in $1 \mathrm{ml}$ of TRIzol (Invitrogen; Thermo Fisher Scientific, Inc., Waltham, MA, USA) to preserve the white cell lysates, which were stored at $-80^{\circ} \mathrm{C}$ until RNA extraction.

Clean-catch urine samples $(10 \mathrm{ml})$ were collected in universal sample pots. These samples were frozen and stored at $-20^{\circ} \mathrm{C}$ until the analysis was conducted.

Determination of ionic circulating and urinary levels of $\mathrm{Co}$ and $\mathrm{Cr}$. Inductively coupled plasma mass spectrometry (ICP-MS; Perkin Elmer Inc., Waltham, MA, USA) equipped with dynamic cell reaction (ELAN DRC II, Perkin Elmer Inc.) was used for the measurements. A reaction system with ammonia gas was used for the elimination of spectral interferences.

Blood samples were diluted (1:20) with $0.05 \%$ Triton X-100 while urine samples were diluted with bi-distilled water, for inorganic trace analysis (Merck KgaA, Darmstadt, Germany).

The calibration curve and the sample solutions were pumped in the spray chamber using a peristaltic pump. Blank samples were used to correct for any contamination in each batch. The concentration of metal ions was expressed as $\mu \mathrm{g} / 1$. The calibration curve was prepared by dilution of a standard solution ranging from 0.5 to $1,000 \mathrm{mg} / 1$ (cobalt in $\mathrm{HNO}_{3}$ $2 \%$ mono elemental standard solution, Carlo Erba Reagenti, Milano, Italy; chromium in $\mathrm{HCl}$ atomic absorption standard solution, Sigma-Aldrich). The procedure followed was previously described $(28,29)$.

The accuracy of the method was verified by comparison with certified reference materials for blood obtained from the German External Quality Assessment Scheme (Institute for Occupational, Social and Environmental Medicine, Erlangen, Germany). The coefficients of variation ranged from 4 to $8 \%$ and the limit of detection, calculated as three standard deviations of the background signal obtained on 10 blinded samples, was $0.05 \mu \mathrm{g} / 1$ in all matrices (whole blood and urine). 
Table I. Patients demographic characteristics and metal ions distribution.

\begin{tabular}{|c|c|c|c|}
\hline Characteristic & Non-prosthetic group & Prosthetic group & P-value \\
\hline Age, years (mean+SEM) & $64.2 \pm 2.1$ & $64.9 \pm 1.9$ & - \\
\hline \multicolumn{4}{|l|}{ Gender } \\
\hline Male & 5 & 5 & - \\
\hline Female & 17 & 17 & - \\
\hline \multicolumn{4}{|l|}{ Smoking habit } \\
\hline Non-smokers (n) & 18 & 18 & - \\
\hline Smokers (n) & 4 & 4 & - \\
\hline Time from implant (years) range & $3.5-15$ & - & - \\
\hline Co-blood $(\mu \mathrm{g} / \mathrm{l})$ range & $0.09-0.65$ & $0.40-35.70$ & 0.0001 \\
\hline Cr-blood $(\mu \mathrm{g} / \mathrm{l})$ range & $0.03-2.03$ & $0.05-12.50$ & 0.0001 \\
\hline Co-urine $(\mu \mathrm{g} / 1)$ range & $0.20-1.50$ & $2.00-867.00$ & 0.0001 \\
\hline Cr-urine $(\mu \mathrm{g} / \mathrm{l})$ range & $0.08-0.90$ & $1.00-138.20$ & 0.0001 \\
\hline
\end{tabular}

SEM, standard error of the mean; Co, cobalt; $\mathrm{Cr}$, chromium.

The exclusion criteria of the American Conference of Governmental Industrial Hygienists recommendation for very diluted (creatinine concentrations less than $0.3 \mathrm{~g} / \mathrm{l}$ ) or very concentrated (creatinine concentration greater than $3.0 \mathrm{~g} / \mathrm{l}$ ) urine samples were adopted (30). Urinary creatinine was determined by a modified Jaffè reaction (ILab 350 Clinical Chemistry System, Instrumentation Laboratories SpA, Bedford, MA, USA).

RNA extraction and reverse transcription. From the white cell lysates, the aqueous phase containing RNA was isolated using TRIzol and total RNA was purified following the clean-up protocol of the RNeasy Mini kit (Qiagen, Valencia, CA, USA). RNA quantity and quality was analysed using a spectophotometer (Nanodrop ND 1000; Thermo Fisher Scientific, Inc.) and genomic DNA contamination was excluded by RNA gel electrophoresis in 1\% agarose gel in 1X TAE (Merck \& Co., Whitehouse Station, NJ, USA) stained with $0.5 \mu \mathrm{g} / \mathrm{ml}$ ethidium bromide (Sigma-Aldrich) and visualized with UV-light.

RNA was subjected to reverse transcription using the following: $1 \mu \mathrm{g}$ total RNA, 200 units Moloney murine leukaemia virus reverse-transcriptase (Promega Corporation, Madison, WI, USA; used with companion buffer), $2.5 \mu \mathrm{M}$ oligo dT-15 (Sigma-Aldrich), $2 \mu \mathrm{M}$ random hexamers (Sigma-Aldrich) and $500 \mu \mathrm{M}$ dNTPs (Takara Biotechnology Co., Ltd., Shiga, Japan). RT reaction was performed in a final volume of $25 \mu \mathrm{l}$ for $60 \mathrm{~min}$ at $37^{\circ} \mathrm{C}$. In order to verify that the RT reaction was successful, amplification of the human glyceraldehyde 3-phosphate dehydrogenase $(G A P D H)$ gene was performed, using specific primers (GAPDH forward: 5'-GAA ATCCCATCACCATCTTCCAG-3' and reverse: 5'-AGGAGA CCACCTGGTGCTCAGTGTAGC-3'). GAPDH amplification was performed in a final volume of $25 \mu \mathrm{l}$, containing $1 \mu \mathrm{l}$ cDNA, $0.2 \mu \mathrm{M}$ each primer, $12.5 \mu \mathrm{l}$ BioMix Red (Bioline, Taunton, MA, USA) under the following conditions: Initial denaturation for $2 \mathrm{~min}$ at $94^{\circ} \mathrm{C} ; 25$ cycles of $30 \mathrm{sec}$ at $94^{\circ} \mathrm{C}$, $30 \mathrm{sec}$ at $61^{\circ} \mathrm{C}$ (annealing temperature of $G A P D H$ primers), $30 \mathrm{sec}$ at $72^{\circ} \mathrm{C}$ followed by a final extension for $7 \mathrm{~min}$ at $72^{\circ} \mathrm{C}$.
Amplicon detection was performed by gel electrophoresis in $1.5 \%$ agarose gel as aforementioned.

Quantitative -polymerase chain reaction $(q P C R)$. qPCR was performed using the CFX-96 system (Bio-Rad Laboratories, Inc., Hercules, CA, USA). Amplification of $5 \mu$ l diluted cDNA (i.e. $25 \mathrm{ng}$ ) were amplified in $20-\mu 1$ reactions using Sso Advanced SYBR Green Supermix (Bio-Rad Laboratories, Inc.) according to the manufacturer's instructions. Following an initial denaturation step at $95^{\circ} \mathrm{C}$ for $2 \mathrm{~min}$, temperature cycling was initiated. Each cycle consisted of $95^{\circ} \mathrm{C}$ for $5 \mathrm{sec}$, and $60^{\circ} \mathrm{C}$ for $30 \mathrm{sec}$ repeated 40 times with the fluorescence being read at the end of this step. The primers were obtained from the PrimePCR SYBR Green Assay (Bio-Rad Laboratories, Inc.) and were specific for human $H M O X-1, G A P D H$, hypoxanthine phosphoribosyltransferase 1 (HPRT1) and TATA-box binding protein $(T B P)$. Every sample was amplified as a technical duplicate and its specificity was evaluated with the melting curves, performed from 65 to $95^{\circ} \mathrm{C}$ for 2 sec every $0.5^{\circ} \mathrm{C}$.

The quality of technical duplicates was established setting a $\mathrm{Cq}$ value of 0.3 as the limit for the standard deviation. The quality of the reference genes was evaluated based on their $M$ value $(<0.5)$, calculated by the CFX Manager software (version 3.1, Bio-Rad Laboratories, Inc.).

$H M O X-1$ relative expression was determined using the $2^{-\Delta \Delta \mathrm{Cq}}$ method (31) with GAPDH, HPRT1 and TBP as reference genes.

Analysis of HMOX-1 protein expression. The concentration of HMOX-1 in the serum was measured using an anti-human HMOX-1 enzyme-linked immunosorbent assay. kit (Enzo Life Sciences, Inc. Farmingdale, NY, USA), whose detection range for HMOX-1 concentration was $0.78-25 \mathrm{ng} / \mathrm{ml}$, according the manufacturer's instructions for undiluted samples. This analysis was conducted on 39 out of 44 total samples due to of lack of samples or reagents.

Statistical analysis. In order to evaluate the differences between the prosthetic and non-prosthetic groups in circulating 
and urinary $\mathrm{Co}$ and $\mathrm{Cr}$ values, the Mann-Whitney test was used. The same test was used to analyze the difference in serum protein levels of HMOX-1 between patients with circulating values $>7 \mu \mathrm{g} / \mathrm{l}$ (high) and $<7 \mu \mathrm{g} / 1$ (low), this threshold was selected in agreement with previous studies $(6,21)$. The same test was used to analyze difference of expression levels of HMOX-1, between prosthetic and non-prosthetic patients, or between those with high and low ion levels. For the correlation between $\mathrm{Co}$ and $\mathrm{Cr}$ levels in the blood and urine and the gene and protein levels of HMOX-1 the Pearson's correlation test was used. $\mathrm{P}<0.05$ was considered to indicate a statistically significant difference.

Statistical analysis and graphs were conducted using SPSS software (version 14.0; SPSS Inc., Chicago, IL, USA).

\section{Results}

Difference in circulating and urinary Co and Cr levels in the prosthetic and non-prosthetic groups. Circulating blood Co levels ranged between 0.09 and $0.65 \mu \mathrm{g} / \mathrm{l}$ and urine levels ranged between 0.2 and $1.5 \mu \mathrm{g} / 1$ in controls, while in patients from the prosthetic group these values ranged between 0.4 and $35.7 \mu \mathrm{g} / \mathrm{l}$ in blood and between 2 and $867.1 \mu \mathrm{g} / \mathrm{l}$ in urine, in this group 15 out of 22 patients had Co $<7 \mu \mathrm{g} / 1$; the difference between controls and prosthetic patients was significant $(\mathrm{P}<0.0001)$ as determined using the Mann-Whitney test. Circulating blood $\mathrm{Cr}$ levels ranged between 0.03 and $2.03 \mu \mathrm{g} / \mathrm{l}$ in controls, while in the prosthetic group these values ranged between 0.05 and $12.50 \mu \mathrm{g} / \mathrm{l}$. In urine samples the $\mathrm{Cr}$ values ranged between 0.08 and $0.90 \mu \mathrm{g} / 1$ in controls and between 1.00 and $138.20 \mu \mathrm{g} / \mathrm{l}$ in the prosthetic group; in this group 17 out of 22 patients had $\mathrm{Cr}<7 \mu \mathrm{g} / \mathrm{l}$. The difference between controls and patients in the prosthetic group was significant $(\mathrm{P}<0.0001)$ using the Mann-Whitney test. These results are summarized in Table I.

Difference in gene expression of $H M O X-1$ between the prosthetic and non-prosthetic groups. Gene expression of $H M O X-1$ in patients in the prosthetic group compared with controls, regardless of $\mathrm{Co}$ and $\mathrm{Cr}$ levels, did not differ significantly using the Mann-Whitney test $(\mathrm{P}=0.581)$. Even when samples were stratified by Co levels, no statistically significant differences were observed $(\mathrm{P}=0.837)$ using the Mann-Whitney test. In subjects with high levels of Co, HMOX-1 expression was $1.05 \pm 0.15$ folds the paired controls value, while in subjects with low levels of Co HMOX-1 expression was $1.02 \pm 0.13$ folds the paired controls value (Fig. 1).

The same analysis was conducted based on circulating $\mathrm{Cr}$ values. HMOX-1 expression in prosthetic patients with high levels of $\mathrm{Cr}$ compared to those with low levels of $\mathrm{Cr}$ was not identified to be statistically different $(\mathrm{P}=0.802)$ using the Mann-Whitney test. The relative mRNA levels in patients with low levels of $\mathrm{Cr}$ was $1.00 \pm 0.04$ fold compared with controls, and 1.10 \pm 0.20 fold compared with controls in patients with high levels of $\mathrm{Cr}$ (Fig. 2). In summary, for high $\mathrm{Cr}$ and $\mathrm{Co}$ groups and for low $\mathrm{Cr}$ and $\mathrm{Co}$ groups, the HMOX1 gene expression was increased, compared with the respective coupled control groups.

In addition, $H M O X-1$ expression was also evaluated in the samples stratified by gender $(\mathrm{P}=0.901)$, age $(\mathrm{P}=0.413)$ and smoking habits $(\mathrm{P}=0.598)$, but no significant differences were observed.

Difference in protein expression of HMOX-1 between the prosthetic and non-prosthetic groups. Protein expression of $H M O X-1$ in serum ranged from 1.8 to $7.7 \mathrm{ng} / \mathrm{ml}$ in patients in the prosthetic group, while it ranged from 2.4 to $9.2 \mathrm{ng} / \mathrm{ml}$ in controls with median values of 5.5 and $4.7 \mathrm{ng} / \mathrm{ml}$, respectively (Fig. 3). Protein expression of HMOX-1 was not statistically different among prosthetic patients and controls ( $\mathrm{P}=0.143)$, as well as among patients with high circulating metal ions and low circulating metal ions $(\mathrm{P}=0.494)$ using the Mann-Whitney test.

Correlation between Co and Cr levels in the blood and urine, and the gene and protein levels of HMOX-1. Finally, the Pearson test did not identify any correlation between gene and protein expression of HMOX-1 ( $\mathrm{r}=-0.06 ; \mathrm{P}=0.74)$, nor between gene and protein HMOX-1 expression and Co blood $(\mathrm{r}=0.11$; $\mathrm{P}=0.48$ and $\mathrm{r}=0.01 ; \mathrm{P}=0.93)$ and urinary $(\mathrm{r}=-0.1 ; \mathrm{P}=0.52$ and $\mathrm{r}=-0.06 ; \mathrm{P}=0.74$ ) levels in the studied sample.

There was no significant correlation between gene and protein expression of HMOX-1 and the $\mathrm{Cr}$ blood $(\mathrm{r}=0.22$; $\mathrm{P}=0.16$ and $\mathrm{r}=0.09 ; \mathrm{P}=0.59)$ and urine $(\mathrm{r}=0.02 ; \mathrm{P}=0.92$ and $\mathrm{r}=0.02 ; \mathrm{P}=0.90)$ values.

\section{Discussion}

The accumulation of metal ions is considered, together with other factors, responsible for the high failure rates of MoM big head hip devices. In a number of studies, the presence of these ions was associated with the induction of oxidative stress (32-40).

Since HMOX-1 is one of the most important antioxidant enzymes to be induced by the presence of metal ions, the aim of the present study was to verify whether, in patients with MoM hip prosthesis, mRNA and protein expression of HMOX-1 was correlated with the level of released metal ions. This was investigated by comparing with patients without prostheses and intentionally not considering implant manufacturers, diameters and performances of the devices, but only the level of metal released.

mRNA and protein expression of HMOX-1 was not identified to be statistically different between patients in the prosthetic and non-prosthetic groups, as well as between patients with high and low ion levels. Moreover, no correlation was identified between the expression of the HMOX-1 gene and its relative protein. This may be due to the use of white blood cells to determine gene expression and the use of the serum alone for the protein assays. Despite the significant differences identified in the ion values between patients in the prosthetic and non-prosthetic groups, there was no correlation between $\mathrm{Co}$ and $\mathrm{Cr}$ levels and $\mathrm{HMOX}-1$ gene expression.

HMOX-1 production (the predicted physiological response) is induced by the increase of metallic ions; however, it is limited in the high ions group. This production is often not enough to avoid circulating ions contributing to the formation of ROS, which may lead to cellular damage and later, the symptoms reported by patients with prosthetic hips. 


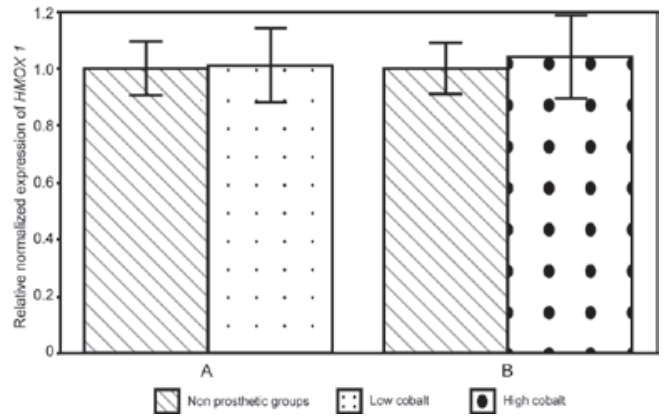

Figure 1.HMOX-1 gene expression differences between patients with varying concentration of $\mathrm{Co}$ in the blood. HMOX-1 gene expression in the patients from the prosthetic group with (A) low levels of cobalt $(<7 \mu \mathrm{g} / \mathrm{l})$ and (B) high levels of cobalt $(>7 \mu \mathrm{g} / \mathrm{l})$ compared with their non-prosthetic controls. $\mathrm{y}$-axis, fold change ( \pm standard error of the mean).

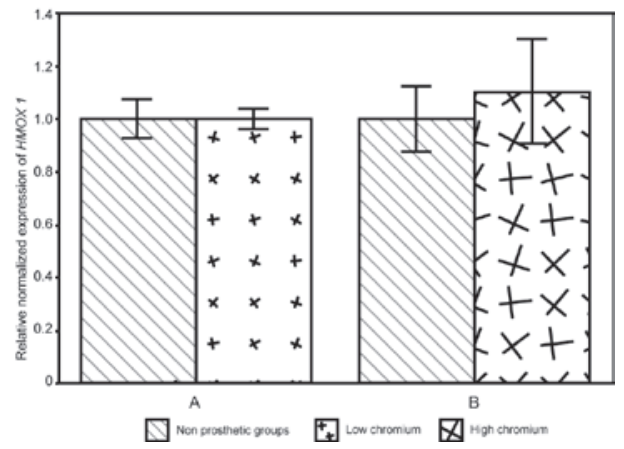

Figure 2. HMOX-1 gene expression differences between patients with varying concentration of $\mathrm{Cr}$ in the blood. HMOX-1 gene expression in patients from the prosthetic group with (A) low levels of chromium $(<7 \mu \mathrm{g} / \mathrm{l})$ and (B) high levels of chromium $(>7 \mu \mathrm{g} / \mathrm{l})$ compared with their non-prosthetic controls. $y$-axis, fold change ( \pm standard error of the mean).

The levels of HMOX-1 identified in the present study were lower than expected in high Co patients, this may be due to the fact that in the current study, the exposure to Co was from an internal source, whereas in other studies where HMOX-1 was overexpressed, the source of Co was external $(36,38,41)$. In the present study conditions, the stimulus that should induce oxidative stress, is the internal continuous chronic release of ions as the patients have had the prosthesis for at least 3.5 years, However, in a previous study subjects ingested a bolus or have received injection/drugs with high concentrations of Co (42).

HMOX-1 was selected as an enzyme involved in oxidative stress response, as there are numerous studies in the literature that support the correlation between HMOX-1 and metal ion concentration. In vitro studies demonstrated that Co (II) dose- and time-dependently induces HMOX-1 expression in different cell lines $(33,40)$. In addition, in vivo studies that demonstrated HMOX-1 induction by Co, were conducted predominantly in the seventies and eighties (36-38), while the most recent studies were conducted in animal models $(32,34,35,39)$. In these studies $\mathrm{Cr}$ appears to exhibit a different role on HMOX-1, depending on whether it is in the $\mathrm{Cr}$ (III) or Cr (VI) form. Indeed, it has been demonstrated that $\mathrm{Cr}$ (III) can be reduced to $\mathrm{Cr}$ (II) by biological reductants (i.e. 1-cysteine and NADPH), which in turn react with hydrogen peroxide via the Fenton reaction to produce hydroxyl radicals.

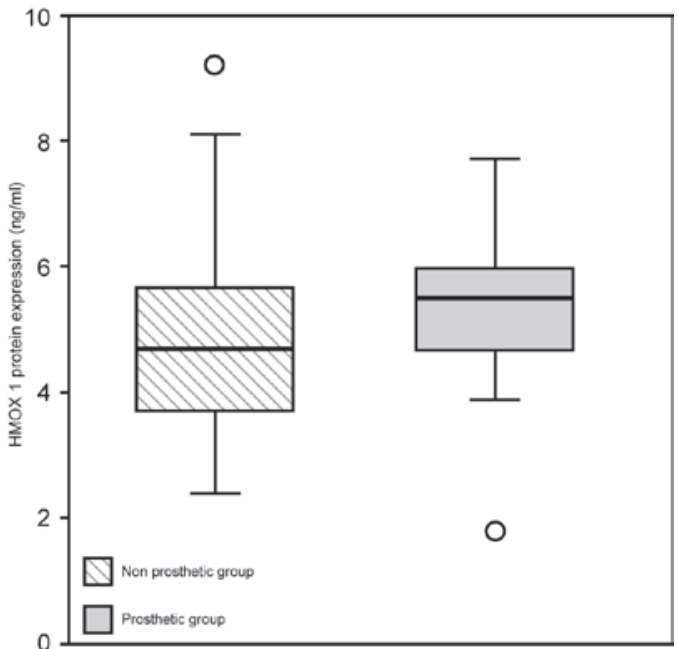

Figure 3. Box plot for protein expression of HMOX-1. Boxes are limited by values of the 25 th and 75 th percentile. The horizontal line crossing the box represents the median value. The vertical lines are extended from min to max value. Outliers are indicated by ${ }^{\circ}$, depending on their distance from 75 th percentile (greater than 3 interquartile differences or greater than 1.5).

However, Cr (VI)-induced cytotoxicity and overexpression of $H M O X-1$ were shown to be dependent on the glutathione level (43).

Therefore, it cannot be excluded that the molecular mechanisms involved in the present study could be different or differently regulated from those observed in other studies. For that reason it would be noteworthy in future studies to measure HMOX-1 levels present in the synovial fluid, where a regulation of the expression similar to that found in this study cannot be ruled out. The discrepancy between the results in the present study and previous literature is possibly due to the small sample size, which had a few uncommon cases, that may have influenced the results.

In the current study, the expression level of HMOX-1 was not affected by the presence of Co, this may be due to the species of Co that was investigated here, the majority of the evidence of interactions between HMOX-1 and Co is in relation to the Co (II) species; however, it is possible that in the present study the Co metallic form $\left(\mathrm{Co}^{0}\right)$ may also be involved. Occupational exposure to hard metal dust (WC-Co) induced effects similar to those of exposure to Co (II) via a different molecular mechanism which does not involve HMOX-1 $(44,45)$. Metallic Co is able to produce ROS; however, the kinetics of this process is slower due to the reduced capacity of oxygen to bind to the surface of the metallic particles (46). In addition, $\mathrm{Co}^{0}$ does not react with $\mathrm{H}_{2} \mathrm{O}_{2}$ via the Fenton reaction (43) and for this reason, if $\mathrm{Co}^{0}$ was the predominant species circulating, this could explain the results of the present study.

Conversely, as far as the lack of effect of circulating $\mathrm{Cr}$ on HMOX-1 induction is concerned, this is probably due to the fact that only $\mathrm{Cr}$ (III) was circulating and does not appear to exert any direct effect on HMOX-1 (43). Previous studies $(47,48)$, have demonstrated that the $\mathrm{Cr}$ released by MoM prostheses and present in circulation is in the $\mathrm{Cr}$ (III) form. This was confirmed by preliminary evaluations of a small group of samples, in which the chemical speciation was determined by hyphenated techniques (HPLC-ICP-MS), investigating the concentration 
of $\mathrm{Cr}$ (III) and $\mathrm{Cr}$ (VI) in the synovial fluid of patients with prostheses, confirming that the only species present is $\mathrm{Cr}$ (III) (unpublished data from Laboratory of Toxicology and Industrial Hygiene, University of Brescia, Italy). Therefore, the results of this study confirm the requirement for greater comprehension of the following for $\mathrm{Co}$ and $\mathrm{Cr}$ : Ion transport within the organism once released by MoM prosthesis, the identity of the species involved, movement of the ions and the mechanisms of elimination. This has also be suggested by Paustenbach et al (49) who hypothesized the existence of a subjective susceptibility to Co (possibly correlated with low albumin levels), which may explain its varied response and transport within the organism. In this case, the identification of individual susceptibility markers, detectable in the peripheral blood, would be an innovative element for investigation of the mechanism by which a patient with a $\mathrm{Co}-\mathrm{Cr}$ prosthesis may react to Co ions.

Despite the limitations highlighted, the methodology in the present study was robust and accurate. The preliminary results obtained here may be extrapolated to a wider context and suggest that $\mathrm{Co}$ and $\mathrm{Cr}$ ions, released by articular prostheses, do not induce an increase in HMOX-1 gene and protein expression at least 3.5 years following the insertion of the implant. However, the involvement of other metal-induced oxidative stress enzymes cannot be excluded and will be the subject of future studies.

\section{Acknowledgements}

The present study was supported by the Italian Ministry of Health for 'Early diagnosis of pending failure in hard bearings' (grant no. RF-2009-1472961) and by the Fondazione Del Monte di Bologna e Ravenna. The authors would like to thank the Orthopaedic surgeons and nursing staff of the Prosthetic Surgery and Revisions of Hip and Knee Implants Division (Rizzoli Orthopaedic Institute, Bologna, Italy) as well as Dr Marilina Amabile for their contribution to sample collection; Dr Lucia Mancini for her support in revising the manuscript; and Dr Marco Bianchi, (Bio-Rad Laboratories, Inc.), for his technical support.

\section{References}

1. De Steiger RN, Hang JR, Miller LN, Graves SE and Davidson DC: Five-year results of the ASR XL acetabular system and the ASR hip resurfacing system: An analysis from the Australian orthopaedic association national joint replacement registry. J Bone Joint Surg Am 93: 2287-2293, 2011.

2. Wienroth M, McCormack P and Joyce TJ: Precaution, governance and the failure of medical implants: The ASR((TM)) hip in the UK. Life Sci Soc Policy 10: 19, 2014

3. Wong JM, Liu YL, Graves S and de Steiger R: What is the rerevision rate after revising a hip resurfacing arthroplasty? Analysis from the AOANJRR. Clin Orthop Relat Res 473: 3458-3464, 2015.

4. SCENIHR: Scientific Committee on Emerging and Newly Identified Health Risks. Final opinion on the safety of metal-on-metal joint replacements with a particular focus on hip implants. 2014. Downloadable at: http://ec.europa.eu/health/ scientific_committees/consultations/public_consultations/ scenihr_consultation_20_en.htm. (Accessed: 27/02/2015).

5. FDA:FoodandDrug Administration.Meeting materialsof theorthopaedicandrehabilitationdevicespanel.2012.Downloadableat:www. fda.gov/AdvisoryCommittees/CommitteesMeetingMaterials/ MedicalDevices/MedicalDevicesAdvisoryCommittee/ OrthopaedicandRehabilitationDevicesPanel/ucm309184.htm (Accessed: 27/02/2015).
6. Günther KP, Schmitt J, Campbell P, Delaunay CP, Drexler H, Ettema HB, García-Cimbrelo E, Hannemann F, Hartmann A, Huberti $\mathrm{H}$, et al: Consensus statement 'Current evidence on the management of metal-on-metal bearings'. Hip Int 23: 2-5, 2013.

7. AOANJRR: Australian orthopaedic association national joint replacement registry. Annual report 2014. Downloadable at: https://aoanjrr.dmac.adelaide.edu.au/annual-reports-2014. (Accessed: 03/02/2015)

8. NJR: National joint registry for England, Wales and Northern Ireland. 11th annual report 2014 and supplementary report metal on metal bearing surface total conventional hip arthroplasty. Downloadable at: http://www.njrcentre.org.uk/njrcentre/ Portals/0/Documents/England/Reports/11th annual_report/ NJR\%2011th\%20Annual\%20Report\%202014.pdf. (Accessed: 03/02/2015).

9. RIPO: Register of the orthopaedic prosthetic implants (Emilia-Romagna, Italy). Annual report 2013. Downloadable at: https://ripo.cineca.it. (Accessed: 03/02/2015).

10. The New Zealand joint registry: 15th Annual report 2013. Downloadable at: http://www.nzoa.org.nz/nz-joint-registry. (Accessed: 03/02/2015).

11. Pastides PS, Dodd M, Sarraf KM and Willis-Owen CA: Trunnionosis: A pain in the neck. World J Orthop 4: 161-166, 2013.

12. De Haan R, Pattyn C, Gill HS, Murray DW, Campbell PA and De Smet K: Correlation between inclination of the acetabular component and metal ion levels in metal-on-metal hip resurfacing replacement. J Bone Joint Surg Br 90: 1291-1297, 2008.

13. Langton DJ, Jameson SS, Joyce TJ, Hallab NJ, Natu S and Nargo AV: Early failure of metal-on-metal bearings in hip resurfacing and large-diameter total hip replacement: A consequence of excess wear. J Bone Joint Surg Br 92: 38-46, 2010.

14. Morlock MM, Bishop N, Zustin J, Hahn M, Rüther W and Amling M: Modes of implant failure after hip resurfacing: Morphological and wear analysis of 267 retrieval specimens. J Bone Joint Surg Am 90 (Suppl 3): 89-95, 2008.

15. Bradberry SM, Wilkinson JM and Ferner RE: Systemic toxicity related to metal hip prostheses. Clin Toxicol (Phila) 52: 837-847, 2014.

16. Konttinen YT and Pajarinen J: Adverse reactions to metal-on-metal implants. Nat Rev Rheumatol 9: 5-6, 2013.

17. Tvermoes BE, Paustenbach DJ, Kerger BD, Finley BL and Unice KM: Review of cobalt toxicokinetics following oral dosing: Implications for health risk assessments and metal-on-metal hip implant patients. Crit Rev Toxicol 45: 367-387, 2015.

18. Tyson-Capper AJ, Lawrence H, Holland JP, Deehan DJ and Kirby JA: Metal-on-metal hips: Cobalt can induce an endotoxin-like response. Ann Rheum Dis 72: 460-461, 2013.

19. Catalani S, Rizzetti MC, Padovani A and Apostoli P: Neurotoxicity of cobalt. Hum Exp Toxicol 31: 421-437, 2012.

20. ACGIH: American conference of industrial hygienists. TLVs $®$ and BEIs®: Threshold limit values for chemical and physical agents and biological exposure indices. Cincinnati, USA. 2014. Downloadable at: http://www.acgih.org. (Accessed: 27/02/2015).

21. MHRA: The medicine and Health care products regulatory agency. Medical device alert. Device: All metal-on-metal (MoM) hip replacement. 2012. Downloadable at: https://assets.digital. cabinet-office.gov.uk/media/5485abf6ed915d4c10000273/ con155767.pdf. (Accessed: 27/02/2015);

22. Estey MP, Diamandis EP, Van Der Straeten C, Tower SS, Hart AJ and Moyer TP: Cobalt and chromium measurement in patients with metal hip prostheses. Clin Chem 59: 880-886, 2013.

23. Angelé-Martínez C, Goodman C and Brumaghim J: Metal-mediated DNA damage and cell death: Mechanisms, detection methods and cellular consequences. Metallomics 6: 1358-1381, 2014.

24. Srivastava KK and Kumar R: Stress, oxidative injury and disease. Indian J Clin Biochem 30: 3-10, 2015.

25. Beyersmann D and Hartwig A: Carcinogenic metal compounds: Recent insight into molecular and cellular mechanisms. Arch Toxicol 82: 493-512, 2008.

26. Maines MD: Heme oxygenase: Function, multiplicity, regulatory mechanisms and clinical applications. FASEB J 2: 2557-2568, 1988.

27. Choi AM and Alam J: Heme oxygenase-1: Function, regulation and implication of a novel stress-inducible protein in oxidant-induced lung injury. Am J Respir Cell Mol Biol 15: 9-19, 1996.

28. Pazzaglia UE, Apostoli P, Congiu T, Catalani S, Marchese M and Zarattini G: Cobalt, chromium and molybdenum ions kinetics in the human body: Data gained from a total hip replacement with massive third body wear of the head and neuropathy by cobalt intoxication. Arch Orthop Trauma Surg 131: 1299-1308, 2011. 
29. Catalani S, Fostinelli J, Gilberti ME and Apostoli P: Application of a metal free high performance liquid chromatography with inductively coupled plasma mass spectrometry (HPLC-ICP-MS) for the determination of chromium species in drinking and tap water. Inter J Mass Spect 387: 31-37, 2015.

30. World Health Organization WHO: Biological Monitoring of chemical exposure in the workplace. Guidelines. Geneva: World Health Organization 1996: Vol. 1.

31. Bustin SA, Benes V, Garson JA, Hellemans J, Huggett J, Kubista M, Mueller R, Nolan T, Pfaffl MW, Shipley GL, et al: The MIQE guidelines: Minimum information for publication of quantitative real-time PCR experiments. Clin Chem 55: 611-622, 2009.

32. Dai Y, Li W, Zhong M, Chen J, Liu Y, Cheng Q and Li T: Preconditioning and post-treatment with cobalt chloride in rat model of perinatal hypoxic-ischemic encephalopathy. Brain Dev 36: 228-240, 2013.

33. Fleury C, Petit A, Mwale F, Antoniou J, Zukor DJ, Tabrizian M and Huk OL: Effect of cobalt and chromium ions on human MG-63 osteoblasts in vitro: Morphology, cytotoxicity and oxidative stress. Biomaterials 27: 3351-3360, 2006.

34. Issan Y, Kornowski R, Aravot D, Shainberg A Laniado-Schwartzman M, Sodhi K, Abraham NG and Hochhauser E: Heme oxygenase-1 induction improves cardiac function following myocardial ischemia by reducing oxidative stress. PLoS One 9: e92246, 2014.

35. Kim S, Lee JC, Cho ES and Kwon J: COMP-Ang1 accelerates chondrocyte maturation by decreasing HO-1 expression. J Cell Biochem 114: 2513-2521, 2013.

36. Maines MD and Kappas A: Cobalt induction of hepatic heme oxygenase; with evidence that cytochrome P450 is not essential for this enzyme activity. Proc Natl Acad Sci USA 71: 4293-4297, 1974.

37. Maines MD and Kappas A: Regulation of heme pathway enzymes and cellular glutathione content by metals that do not chelate with tetrapyrroles: Blockade of metal effects by thiols. Proc Natl Acad Sci USA 74: 1875-1878, 1977.

38. Maines MD, Trakshel GM and Kutty RK: Characterization of two constitutive forms of rat liver microsomal heme oxygenase: Only one molecular species of the enzyme is inducible. J Biol Chem 261: 411-419, 1986
39. Stec DE, Vera T, McLemore GR Jr, Kelsen S, Rimoldi JM, Gadepalli RS and Ryan MJ: Heme oxygenase-1 induction does not improve vascular relaxation in angiotensin II hypertensive mice. Am J Hypertens 21: 189-193, 2008

40. Tkaczyk C, Huk OL, Mwale F, Antoniou J, Zukor DJ, Petit A and Tabrizian M: Effect of chromium and cobalt ions on the expression of antioxidant enzymes in human U937 macrophage-like cells. J Biomed Mater Res A 94: 419-425, 2010.

41. Piotrowski J, Jedrzejewski T and Kozak W: Heme oxygenase-1 induction by cobalt protoporphyrin enhances fever and inhibits pyrogenic tolerance to lipopolysaccharide. J Therm Biol 45: 69-74, 2014

42. Finley BL, Unice KM, Kerger BD, Otani JM, Paustenbach DJ, Galbraith DA and Tvermoes BE: 31-day study of cobalt(II) chloride ingestion in humans: Pharmacokinetics and clinical effects. J Toxicol Environ Health A 76: 1210-1224, 2013.

43. Jomova $\mathrm{K}$ and Valko $\mathrm{M}$ : Advances in metal-induced oxidative stress and human disease. Toxicol 283: 65-87, 2011.

44. De Boeck M, Kirsch-Volders M and Lison D: Cobalt and antimony: Genotoxicity and carcinogenicity. Mutat Res 533: $135-152,2003$.

45. Stefaniak AB, Harvey CJ, Bukowski VC and Leonard SS: Comparison of free radical generation by pre- and post-sintered cemented carbide particles. J Occup Environ Hyg 7: 23-34, 2010.

46. Lison D, De Boeck M, Verougstraete V and Kirsch-Volders M: Update on the genotoxicity and carcinogenicity of cobalt compounds. Occup Environ Med 58: 619-625, 2001

47. Walter LR, Marel E, Harbury R and Wearne J: Distribution of chromium and cobalt ions in various blood fractions after resurfacing hip arthroplasty. J Arthroplasty 23: 814-821, 2008.

48. Beraudi A, Stea S, De Pasquale D, Bordini B, Catalani S, Apostoli $\mathrm{P}$ and Toni A: Metal ion release: Also a concern for ceramic-on-ceramic couplings? Hip Int 24: 321-326, 2014.

49. Paustenbach DJ, Galbraith DA and Finley BL: Interpreting cobalt blood concentrations in hip implant patients. Clin Toxicol (Phila) 52: 98-112, 2014 